\title{
The Relationship Between Psychological Empowerment and Creative Performance of Employees: Mediating Effect of Job Satisfaction in International Non-Governmental Organizations
}

\author{
Dina Ayoub, (BSc) \\ Dania Al-Akhras, (BSc) \\ Ghalia Na'anah, (BSc) \\ Amro Al-Madadha, (PhD)
}

Princess Sumaya University for Technology, Jordan

Doi:10.19044/esj.2018.v14n20p217 URL:http://dx.doi.org/10.19044/esj.2018.v14n20p217

\begin{abstract}
The aim of this study was to examine the relationship between psychological empowerment and creative performance through the mediating effect of job satisfaction in the International Non-Governmental Organization's (INGO's) context in Jordan. In accomplishment of this, an online questionnaire was distributed to a random representative sample of INGO's employees working at Jesuit Refugee Service Jordan. Data were collected from 125 workers who are diverse in their gender, age, educational level, work experience and hierarchical position. Additionally, SPSS and AMO statistical software were used in order to read out the results of the filled out questionnaires. Moreover, Correlation Matrix, Multiple Regression Analysis and Mediation Analysis Process statistical tools were adopted in order to validate the proposed relationship. Sequentially, the results of the analysis validated the proposition that psychological empowerment is correlated significantly to the creative performance of employees through the mediating effect of job satisfaction.
\end{abstract}

Keywords: Psychological Empowerment, Creative Performance, Job Satisfaction, Jordan INGO

\section{Introduction}

Despite the fact that human resources concept has been lately introduced in the MENA Region, the concept has been of interest more than before. Since the past few decades, firms have come to recognize that human factor is a vital driving force of their performance (Pfeffer, 1994; Fiorina 2000, 
Cartwright \& Cooper, 2014). Moreover, human capital is perceived as one of the main building blocks to gain a sustainable competitive advantage, which requires Human Resources Management practices to be aligned with the organization's overall strategy (Barney, 1991, 1995; Lado \& Wilson, 1994, Brewster, 2017). This is due to the fact that humans in their nature are somewhat episodic and depict exceptionally complex creatures, which in turn make such creatures difficult to mimic (Barney, 1991; Peteraf, 1993; Black \& Boal, 1994, Knight, 2016). Therefore, employers should pay considerable attention to what drives people's performance and to what fulfills their needs in order to positively affect organizational performance.

The proposed framework of this research paper links psychological empowerment to the creative performance of employees through the intervening effect of job satisfaction so as to extend literature and to amend employers', of the context in question, prospects regarding the tackled issues.

There is no doubt that empowerment is a key driver of individual and, subsequently, organizational performance (Seibert et al., 2004) as it energizes organization's folks to fully utilize their skills and capabilities to achieve impactful results for their organizations (Vogt \& Murrell, 1990; Chen et al., 2007). Empowerment in its general meaning is permitting staff to establish their own goals and objectives to accomplished, make shared-decisions and overcoming problems that are faced within their responsibilities' boundaries ((Moorhead \& Griffin, 1995; Conger and Kanungo, 1988; Carson et al., 2007; Greasley et al., 2008; Hempel et al., 2012). However, as the concept continues to evolve, many different dimensions/approaches to empowerment have been discovered, most importantly, Psychological Empowerment and SocioStructural Empowerment (Tymon, 1988; Laschinger et al., 2004). SocioStructural Empowerment is enacted by manager's conducts and attitudes; such attitudes drive the psychological state of employees (Dewettinck \& Ameijde, 2011; Seibert et al., 2004; Menon 2001). On the other hand, Conger \& Kanungo (1998) outlined that empowerment is "psychological enabling" furthermore, the authors viewed the practice as the improvement of staff selfefficacy through the elimination of powerlessness elements. It can be addressed that Psychological Empowerment equates; employees' intrinsic motivation and perception of their work represented by four dimensions: "meaning, competence, self-determination and impact" (Spreitzer, 1995; 2008; Lawler, 1986; Thomas \& Velthouse 1990).

Researchers and scholars agreed that empowerment as a motivational construct (psychological empowerment) deals with the mind state of employees. Hence, managers on their side should take the necessary actions of empowerment initiatives in order to positively influence employees' psychological state (Menon, 2001). This will, consequently, result in an improved level of satisfaction (Chiang \& Hsieh, 2012; Kue et al., 2008; Seibert 
et al., 2011). Subsequently, self-efficacy and outcome expectations of Lawler (1973)'s Expectancy Theory will be met and thus enhancing feelings of psychological empowerment (Lawler, 1973; Conger \& Kanungo, 1988; Thomas \& Velthouse, 1990; Spreitzer, 1995; 1997; Meyerson \& Kline, 2008).

Given a turbulent, dynamic and aggressively competitive environment, employees' creative performance is a key to the survival of operating organizations (Anderson et al., 2014; Oldham \& Cummings, 1996; Van Gundy, 1987). Creative performance is described as the initiation of firsthand, original ideas that is potentially valuable and pertinent to the organization (Woodman et al., 1993; Oldham \& Cummings, 1996; Robinson \& Beesley, 2010). Nonetheless, employees' creative performance is directly linked and conditioned by individual and contextual drivers (Tierney et al., 1999; Hennessey \& Amabile, 1998; Flynn \& Goldsmith, 1993; Oldham \& Cummings, 1996; Amabile et al., 1996; Amabile \& Gryskiewicz, 1989) that is to be aligned to one another in order to significantly play a role in fostering employees' creativity (Amabile, 1988; Scott \& Bruce, 1994; Eisenberger et al., 1999). Hence, organizations should be driven by "human values" which means treating employees equally and manipulate their job characteristics through adding a sense of empowerment to their tasks (Spector 1997; Lawler et al., 1995). At this point employees can be internally satisfied with their jobs, this satisfaction will be positively reflected on their behaviors and consequently on their creative performance (Judge et al., 2001; Han et al., 2009).

Having it all gathered, nowadays, the rapidly changing; dynamic; brutal global competitive environmental context of organizations required parties in question to always strive for being the market leaders or initiators of novel ideas for them to stand against competitors' actions and sustain their competitive advantage (Delbecq \& Mills, 1985; Kanter, 1983). With this being the condition of the market, there still lack of literature of psychological empowerment and its effect on the creative performance of employees, which is clearly apparent in the MENA region specifically in Non-Governmental Organization's (NGO's) context. Besides that MENA employers relatively underrate the tackled issues.

As mentioned earlier, the constructed model of this paper connects psychological empowerment to the creative performance of employees through the mediating effect of job satisfaction. The proposed correlations are consistent with extant literature and been agreed by many scholars and researchers. However, to the best of the researchers' knowledge, no one yet examined the mentioned model in the INGO's sector in Jordan. Therefore, this article will extend extant literature's supported hypotheses concerning psychological empowerment and creative performance on Jordan's INGO's context through the intervening effect of job satisfaction as means of 
encouraging concerned people to empower workers, which in turn affect the organization's overall performance.

\section{Theory and Hypotheses}

At this part, the researchers will be discussing the proposed conceptual framework of this article embodied in the projected set of hypotheses. The hypothesized relationships were based on extant literature of empowerment theories. Nonetheless, we will trace the theoretically hypothesized relationships and test our proposed hypotheses in relation to the context in question. The proposed framework suggests the relationship between psychological empowerment and creative performance through the mediating effect of job satisfaction. As figure 1 shows, psychological empowerment is the independent variable, job satisfaction is the mediating variable and creative performance is the dependent variable. This relationship will be examined through the measurement of the effect of psychological empowerment and its dimensions (i.e. meaning, competence, impact and selfdetermination) to provide scientific evidence on its effect on the creative performance of employees through job satisfaction.

Psychological
$\quad>$ Meaning
$\quad>$ Competence
$\quad>$ Impact
$>$ Self-Determination

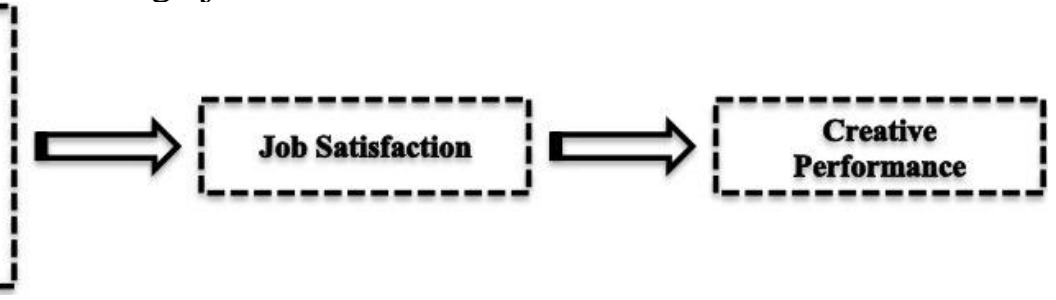

Figure 1 Hypothesized Model.

\section{Psychological Empowerment and Job Satisfaction}

Psychological Empowerment is the independent, decision variable, in our study, and the starting point to motivating creative performance. Consistently, many studies have shown that psychological empowerment and job satisfaction are directly related (Castro et al., 2008; Dewettinck \& Ameijde, 2011; Fong \& Snape 2015) that is the more employees are empowered the more satisfied they will be (Menon, 2001; Stewart, et.al, 2010).

Moreover each of the four dimensions of psychological empowerment shows an increasing relationship with job satisfaction (Spreitzer et al., 1997). To elaborate, psychologically empowered employees undergo satisfaction in various stances (Amundsen \& Martinsen, 2015). To itemize it, when employees perceive work as being personally important their satisfaction levels tend to boost (Spreitzer et al., 1997; Hackman \& Oldham, 1980). In the same manner, their beliefs of personal efficacy and ability to perform task competently are likely to result in higher satisfaction levels (Spreitzer et al., 
1997; Hartline \& Ferrell, 1996). The same applies to Spreitzer et al. (1997); Thomas \& Tymon (1994) who believed that self-determined individuals are more likely to be satisfied than others since self-determination is a key contributor to intrinsic motivation. The fourth dimension, "impact," is intensely linked to job satisfaction. The reason behind that is the ability of employees in such case to recognize the results of their work on the big picture of the organization (Spreitzer et al., 1997; Ashforth, 1989).

Nonetheless, the relationship is yet to be examined and probed, however, some reasonable expectations could be initially set. The set expectations resulted in the first hypothesis of the research study:

H1: Psychological Empowerment is positively related to Job Satisfaction. Hla: Meaning is positively related to Job Satisfaction. H1b: Competence is positively related to Job Satisfaction. H1c: Self-Determination is positively related to Job Satisfaction. Hld: Impact is positively related to Job Satisfaction.

\section{Job Satisfaction and Creative Performance}

Job satisfaction is a key contributor to the creative performance of employees (Bytyqi et al., 2010). As such, we have positioned it as the variable that mediates the effect between Psychological Empowerment and Creative Performance. "Creative and satisfied staffs are the most important asset of an organization and the most competitive advantage and the scariest supply in today's organizations economy" (Taherkhani, 2015). Thus, it is important to scrutinize the mentioned relationship for managers to enrich their understanding on the practices that boost staffs' satisfaction and thus their creative performance.

Many scholars and academics settled that a positive relationship exists between job satisfaction and creative performance. Isen \& Daubman (1984) made a major contribution to this statement when they suggested in their research study that emotional state of pleasure (job satisfaction as mentioned earlier) empowers people to "see relatedness and interconnections among cognitions, and perhaps process material in a more integrated fashion." As a result, information processing and thinking constraints would be eliminated and would increase employees' openness to original ideas and proposals (Taherkhani, 2015). We can arrive at a conclusion then, that job satisfaction leads to a higher level of worker's creative performance, which is represented in our second hypothesis below.

H2: Job Satisfaction is positively related to Creative Performance.

\section{Psychological Empowerment and Creative Performance}

Earlier research suggested that empowerment critically influences employees' creativity in a positive manner (Ambile, 1983). Furthermore, 
Ambile found out that increasing interest in job tasks rather than reward and punishment system triggers creative performance; moreover, people tend to generate novel ideas when they have higher degree of freedom in setting targets and performing tasks.

Digging deeper into the said correlation, each dimension of psychological empowerment is discovered to have a positive influence on employees' creative performance (Spreitzer 1995; Spreitzer et al., 1997; Spreitzer et al., 1999; Jung \& Sosik, 2002). To clarify, when empowered workers realize how personally meaningful their work is, this is likely to reinforce their willingness to accomplish significant objectives (Sun et al., 2012). Besides, those who perceive themselves as being able to perform their tasks skillfully tend to be more "cognitively flexible" and thus more open to adapt new ideas and solutions (Wallace et al., 2011; Wang et al., 2014). Additionally, Spreitzer (1995) reported that staff's intentions to think creatively are found to boost when they can sense the impact of their work on the organization as a whole. Likewise, self- determined workers are highly self-confident, which drives them to always pursue techniques through which their work settings would be improved (Jung \& Sosik 2002; Spreitzer 1995). Heading from this critical relationship, we have proposed the third hypothesis as follows:

H3: Job Satisfaction mediates the effect between Psychological Empowerment and Creative Performance.

\section{Methods}

One of the most important and sensitive stages in handling any research is to identify the methodology and procedures followed to achieve the targets of the research. It is even more important to select valid and reliable measurement scales that enable the researcher to interpret the collected data appropriately and subsequently make a generalization (Yin, 2009).

\section{Data Collection and Participants}

For the purposes of measuring the hypothesized relationship; and testing out the suggested hypotheses, a set of data were collected using quantitative instruments, standardized online questionnaire, which was developed using SurveyMonkey website. The online questionnaire named "Antecedents of Creative Performance" was distributed on a sample of 256 respondents working at one of the International Non-Governmental Organizations, Jesuit Refugee Services (JRS), Jordan branch. The named questionnaire was distributed during the period between 3rd of April 2018 8th of May 2018. The responses were collected in English through an Email sent, along with an URL link to the questionnaire, to Jordan's Country Director of the surveyed INGO to encourage participation. It was clearly stated 
in the sent email that the responses will be confidential and will not include any personal identifying information. As a result, 125 of the circulated questionnaires were serviceable.

In sorting out the pattern regarding demographical characteristics among the navigated sample we found out that, approximately, $46 \%$ of those represent female respondents while male representation in the sample was $44 \%$ worker. Moreover, the majority of the population was aged between 20 and 29 years since the rest of age classes gathered represents only $34 \%$ of the sample. Furthermore, bachelor's degree holders were significantly the dominant class amongst the research society. In contrast, the targeted sample was distributed throughout working experience scale as follows, $42 \%$ of the sample have been working for one year or less at JRS; $50 \%$ have spent two to four years whilst only $9 \%$ have been loyal employees to JRS, working for five years or more. There was a variety of hierarchical positions of those who filled out the questionnaire as managers class demonstrates $25 \%$ of the respondents, officers exemplifies $40 \%$ of the sample whereas assistants class represents $35 \%$ of the surveyed society.

\section{Measurements}

Measurement of the constructs' scales aid researchers to draw conclusions for any deductive research study (Malhorta, 2004). In this respect, nominal scale was adopted to address demographical characteristics of the responder. Covered demographical areas included, responder's gender (Female/ Male); age ranging from twenty-years old to sixty-years old; educational levels from Doctor of Philosophy (Ph.D.) to high school; working period at the responder's organization stretching from less than one year to more than five years; and worker's position (Assistant, Officer or Manager). Based on the nature and the intended uses of the collected data, preset ordinal scales were followed for the purposes of measuring each proposed construct in the theoretical framework (Psychological Empowerment, Job Satisfaction and Creative Performance). The used measurement items for each construct are shown in the Appendix.

\section{Psychological Empowerment}

As mentioned earlier, psychological empowerment is exhibited in four dimensions; "Meaning, Competence, Self-determination and Impact" (Spreitzer, 1995). Spreitzer (1995)'s ordinal 12-point scale, which have been adopted by many scholars and researchers (Kraimer et al., 1999; Huang, 2012), was applied to our questionnaire 'Antecedents of Creative Performance' to find out the level of employee's psychological empowerment in the INGO's sector and in an attempt to validate the researcher's hypotheses. Therefore, a five-point Likert scale was developed for this measurement, 
scoring varied form " 5 " representing "strong agreement" of the responder whereas " 1 " reflects a "strong disagreement", with " 3 " revealing a neutral state. By reading out the scores of the Likert scale, means and standard deviations for each one of the constructs have been calculated. The mean and standard deviation results for the dimensions of Meaning, Competence, Selfdetermination and Impact were, (4.5 and 0.79), (4.49 and 0.68), (3.38 and 0.94 ) and (4.0 and 1.03) respectively. Since the mean values of all of the dimensions were above (3.00) and standard deviation results were less than 1.00 , it can be settled that Jordan INGO's employees reckon that they are exceptionally, psychologically empowered with a convergence of opinions on these feelings of psychological empowerment.

\section{Job Satisfaction}

The current study applies Spector (1994) scale of job satisfaction with the purpose of measuring the mediating role of this construct in the proposed relation. Evidentially, this scale has been adopted in many studies (Lamond \& Spector, 2000) resulting in its validation; as such it was appropriate to follow this scale to measure worker's level of job satisfaction. A corresponding 5point Likert scale was followed; "5" shows a "very satisfied" worker, on the contrary, "1" displays a "very dissatisfied" one. The computation of the Likert scale scores resulted in a job satisfaction mean of 3.82 and a standard deviation of 0.68. It is evidential then that Jordan INGO employees consensually feel that they are satisfied with their jobs.

\section{Creative Performance}

With reliability and validity being requirements for any used scale, this study followed Zhou \& George (2001) 13-item scale of measuring the creative performance of employees. The validity of this scale has been confirmed throughout the years after being used by a considerable number of academics and researchers (Zhou \& Shalley, 2003; Gardner, 2011, Al-Madadha, 2016). Scoring of the matching Likert-type scale ranged from " 5 " refers to an action taken "always" by the responder to " 1 " reflecting an action that has "never" been taken by the employee himself/herself. It was found that Jordan INGO staff perceives themselves as being creative performers since the mean result of this construct was (4.1) and a convergence of opinions regarding this feeling was evidential through standard deviation result of (0.44).

\section{Analysis}

A correlation matrix has been adopted in this research paper to comprehend the connection between the three variables (i.e. psychological empowerment, job satisfaction and creative performance) among the adopted three different measurement scales for each variable and to find out the degree 
by which each variable is correlated positively/negatively to the other variables. A positive correlation between the variables confirms the hypotheses. This statistical tool is serviceable when it comes to the first two hypotheses of our research, however, the third hypothesis of the mediating effect of job satisfaction could not be tested neither could it be validated using correlation matrix. Consequently, multiple regression analysis has been utilized to gauge the independent variables' ability to foretell the value of the dependent variable of the research (Field \& Gillett, 2010; Hair et al., 2010). The usefulness of this approach was apparent in the values of its statistical tools (Beta, $\mathrm{R}^{2}$ and P-Value) each of which supported the hypotheses in different way (Mason \& Perreault, 1991; Cohen et al., 2013). For instance, Beta value shows the degree by which the variables are related to one another; $\mathrm{R}^{2}$ interprets the extent to which the variability of the dependent variable is explained and caused by its antecedents; and P-Value displays the significance of the relationship between the variables. To clarify this further, if P-Value is less than 0.05 this proves a significant relationship between the variables and vice versa. The presence of a mediating variable in the current study, job satisfaction, as a mediating effect between psychological empowerment and creative performance has led us to applying Baron \& Kenny (1986) "Mediation Analysis Process" as it suggests that the independent variable (psychological empowerment) and the dependent variable (creative performance) arerelated to one another indirectly through the mediating variable (job satisfaction). In order for this approach to validate the third hypothesis of our research, which couldn't be tested using the preceding two approaches, two paths were followed, direct and indirect path as shown in figure 2 below. On one hand, the direct path claims that Psychological Empowerment and Creative Performance are directly related without the need for a mediating effect. On the other hand, the indirect path suggests that psychological empowerment and creative performance are linked to one another through the mediating variable of job satisfaction, which is represented by our third hypothesis.

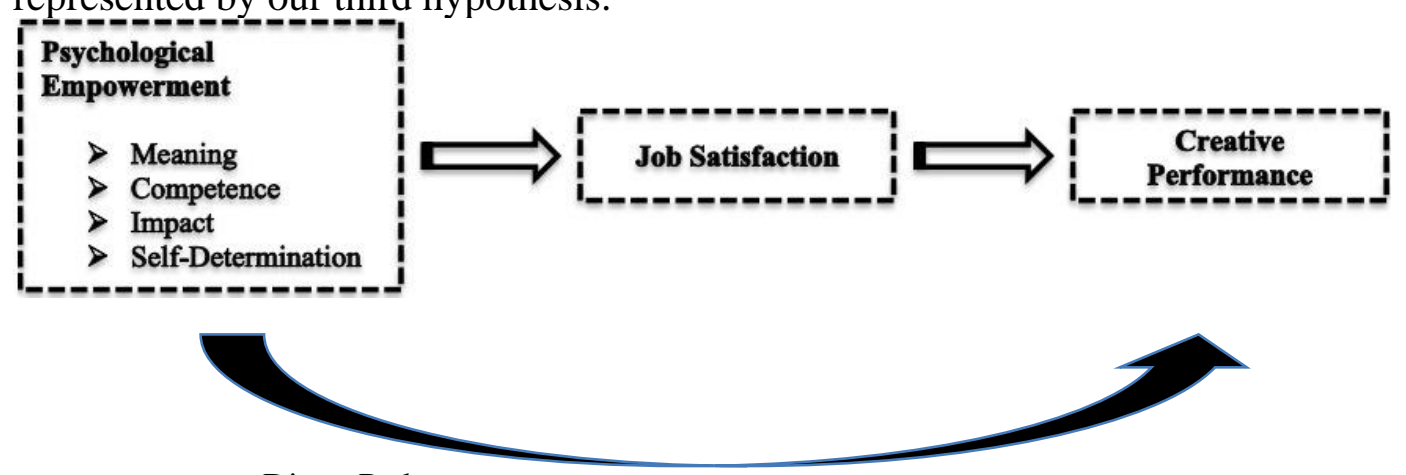

Direct Path

Figure 2: Direct and Indirect Path to Creative Performance 


\section{Results}

\section{Correlation Matrix}

Table 1 demonstrates the correlation matrix amongst the constructs of this paper (i.e. psychological empowerment, job satisfaction and creative performance). Generally speaking, the constructs of the present study are positively correlated. To dig deeper into this, the correlation between psychological empowerment and job satisfaction is evidential through the values of the correlation of job satisfaction with each one of the dimensions; meaning, competence, self-determination and impact, which were 0.457 , $0.235,0.756$ and 0.142 respectively. It is revealed from table 1 that job satisfaction acts as a positive stimulus to creative performance as the value of this correlation was (0.455). To put this in other words, INGOs' employees that retain high levels of job satisfaction are predicted to be creative while doing their jobs and vice versa. Proportionately, as table 1 displays, psychological empowerment and creative performance shows a positive correlation, this is drawn from the presented correlation values between creative performance and psychological empowerment exhibited in its four dimensions as follows; creative performance and meaning (0.235); creative performance and competence (0.326); creative performance and selfdetermination (0.543); and creative performance and impact (0.544)

Table 1: Correlation Matrix Results

\begin{tabular}{|c|c|c|c|c|c|c|c|}
\hline & \multicolumn{4}{|c|}{ Psychological Empowerment } & \multirow[b]{2}{*}{ 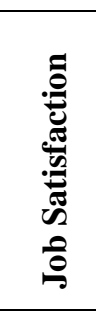 } & \multirow[b]{2}{*}{ 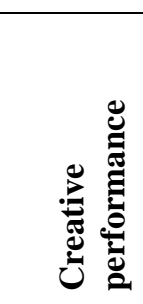 } \\
\hline & & 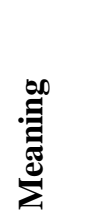 & 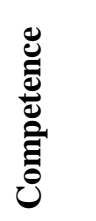 & 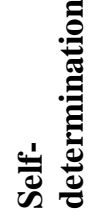 & 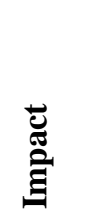 & & \\
\hline \multirow{4}{*}{ 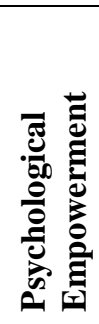 } & Meaning & 1.00 & & & & & \\
\hline & Competence & 0.561 & 1.00 & & & & \\
\hline & $\begin{array}{l}\text { Self- } \\
\text { determination }\end{array}$ & 0.364 & 0.547 & 1.00 & & & \\
\hline & Impact & 0.467 & 0.562 & 0.365 & 1.00 & & \\
\hline \multicolumn{2}{|c|}{ Job Satisfaction } & 0.457 & 0.235 & 0.756 & 0.142 & 1.00 & \\
\hline \multicolumn{2}{|c|}{ Creative Performance } & 0.235 & 0.326 & 0.543 & 0.544 & 0.455 & 1.00 \\
\hline
\end{tabular}

Building upon correlation matrix's scores, a conclusion can be extended that the four dimensions of psychological empowerment has a 
positive impact on job satisfaction. Therefore, job satisfaction is positively correlated to creative performance.

H1: Psychological Empowerment is positively related to Job Satisfaction. H1a: Meaning is positively related to Job Satisfaction. H1b: Competence is positively related to Job Satisfaction. Hlc: Self-Determination is positively related to Job Satisfaction. H1d: Impact is positively related to Job Satisfaction. Supported

H2: Job Satisfaction is positively related to Creative Performance. Supported

\section{Multiple Regression Analysis}

Multiple regression analysis was first applied to the first hypothesis for validation purposes. The results of the analysis are presented below in Table 2.

Table 2: Multiple regression test results on the impact of Psychological Empowerment on job satisfaction

\begin{tabular}{|c|c|c|c|c|c|c|c|}
\hline & \multicolumn{7}{|c|}{ Independent (Psychological Empowerment) } \\
\hline $\begin{array}{l}\text { H1: H1a, H1b, H1c and } \\
\text { H1d }\end{array}$ & Meaning & Competence & $\begin{array}{l}\text { Self- } \\
\text { Determination }\end{array}$ & Impact & $\begin{array}{l}\text { Mode } \\
\text { Statis }\end{array}$ & & Results \\
\hline Dependent & $\mathbf{B}$ & $\mathbf{B}$ & B & B & $\mathbf{R}^{2}$ & $\mathbf{P}$ & $\mathbf{A} / \mathbf{R}$ \\
\hline Job Satisfaction & 0.134 & 0.234 & 0.367 & 0.547 & 0.442 & 0.001 & A \\
\hline
\end{tabular}

From the table above, it is evident that the relationship between psychological empowerment and job satisfaction were statistically significant. This significance is interpreted in the result value of $\mathrm{R}^{2}$ that exhibits a $55 \%$ presentation of job satisfaction's variation by psychological empowerment. This goes in consistent with correlation matrix results. Similar to correlation matrix, each of psychological empowerment dimensions has shown a positive relationship with job satisfaction, as displayed in table 4-4, the results of the dimensions were as follows; meaning and job satisfaction $(\mathrm{B}=0.134)$; competence and job satisfaction $(\mathrm{B}=0.234)$; self-determination and job satisfaction $(B=0.367)$; and Impact and job satisfaction $(B=0.547)$. As such, a conclusion can be drawn that the first hypothesis and its corresponding subhypotheses of this research study were empirically supported.

H1: Psychological empowerment is positively related to job satisfaction.

In testifying the second hypothesis that job satisfaction is significantly and directly related to creative performance, multiple regression analysis results of this hypothesis are shown below in table 3 .

Table 3: Multiple Regression Test Results of Job Satisfaction's impact on Creative Perfomance

\begin{tabular}{|l|l|l|l|l|}
\hline H2 & Independent (Job Satisfaction) & \multicolumn{2}{|l|}{ Model Statics } & Results \\
\hline Dependent Variable & B & $\mathbf{R}^{\mathbf{2}}$ & $\mathbf{P}$ & $\mathbf{A} / \mathbf{R}$ \\
\hline Creative Performance & 0.312 & 0.231 & 0.002 & $\mathrm{~A}$ \\
\hline
\end{tabular}


The second hypothesis proposed that job satisfaction and creative performance are significantly related to one another in a positive correlation. Nonetheless, the results of multiple regression analysis were consistent with those of correlation matrix since the results of the conducted test $\left(R^{2}=0.231\right.$, Beta $=0.312$ and P-Value $=0.002$ ) supported this relationship.

H2: Job satisfaction is positively related to the creative performance of employees.

\section{Mediation Analysis Process}

Mediation analysis enriches one's understanding of the constituents of psychological empowerment (Sibert et al., 2004). The current paper hypothesized the relationship between psychological empowerment and creative performance as mediated through the effect of job satisfaction. In order to test out this hypothesis, we used Baron \& Kenny (1986) "Mediation Analysis Process."

We first applied mediation analysis on the direct path. As shown in table 4 psychological empowerment has a positive effect on job satisfaction. This can be extrapolated from the results of $\mathrm{R}^{2}$ and Beta, which was 0.354 and 0.547 respectively. Moreover, the table demonstrates that psychological empowerment was found to interpret $35 \%$ of the variation in creative performance. This clearly demonstrates the positive significant relationship between psychological empowerment and creative performance.

Table 4: Results for Mediation Analysis (Direct Path)

\begin{tabular}{|c|c|c|c|c|}
\hline & \multirow{2}{*}{\multicolumn{2}{|c|}{$\begin{array}{l}\text { Mediating Effect } \\
\text { Job satisfaction }\end{array}$}} & \multicolumn{2}{|c|}{ Dependent Variable } \\
\hline & & & Creat & Performance \\
\hline Independent Variable & $\mathbf{B}$ & P Value & $\mathbf{B}$ & P Value \\
\hline Psychological Empowerment & 0.354 & 0.000 & 0.324 & 0.000 \\
\hline $\mathrm{R}^{2}$ & \multicolumn{2}{|l|}{0.547} & \multicolumn{2}{|l|}{0.347} \\
\hline
\end{tabular}

Following this, we have applied regression experiment to the entire variables of the research (i.e. psychological empowerment, job satisfaction and creative performance). In this test, the effect of psychological empowerment shall decrease when compared to the preceding mediation analysis test in order to validate the model. Table 5 below displays the results of this test on the indirect path.

Table 5: Results for Mediation Analysis (Indirect Path)

\begin{tabular}{|l|l|l|l|l|}
\hline Variables & \multicolumn{4}{l|}{ Creative Performance } \\
\hline & $\mathbf{B}$ & $\mathbf{P}$ & $\mathbf{R}^{\mathbf{2}}$ & $\underline{\mathbf{P} \text { Value }}$ \\
\hline Psychological Empowerment & 0.121 & 0.354 & $\mathbf{0 . 6 3 2}$ & $\mathbf{0 . 0 0 1}$ \\
\hline Job Satisfaction & 0.296 & 0.000 & $\mathbf{0 3}$ & \\
\hline
\end{tabular}


The results above prove the third hypothesis of the mediation effect of job satisfaction since it is clear that job satisfaction has a significant correlation with creative performance $(\mathrm{P}=0.000)$ whilst psychological empowerment's result $(\mathrm{P}=0.354)$ shows insignificant relation to creative performance. On the top of that, it is clear that beta value of psychological empowerment has decreased in this test. Having said that, it is then applicable that job satisfaction mediates the relationship between psychological empowerment and creative performance since $63 \%$ of creative performance is explained by psychological empowerment through the mediating effect of job satisfaction (indirect path).

H3: job satisfaction mediates the relationship between psychological empowerment and creative performance.

Figure 3 below visualizes the finding that the indirect path represents higher percentage of the variation in the creative performance of employees than the direct path.

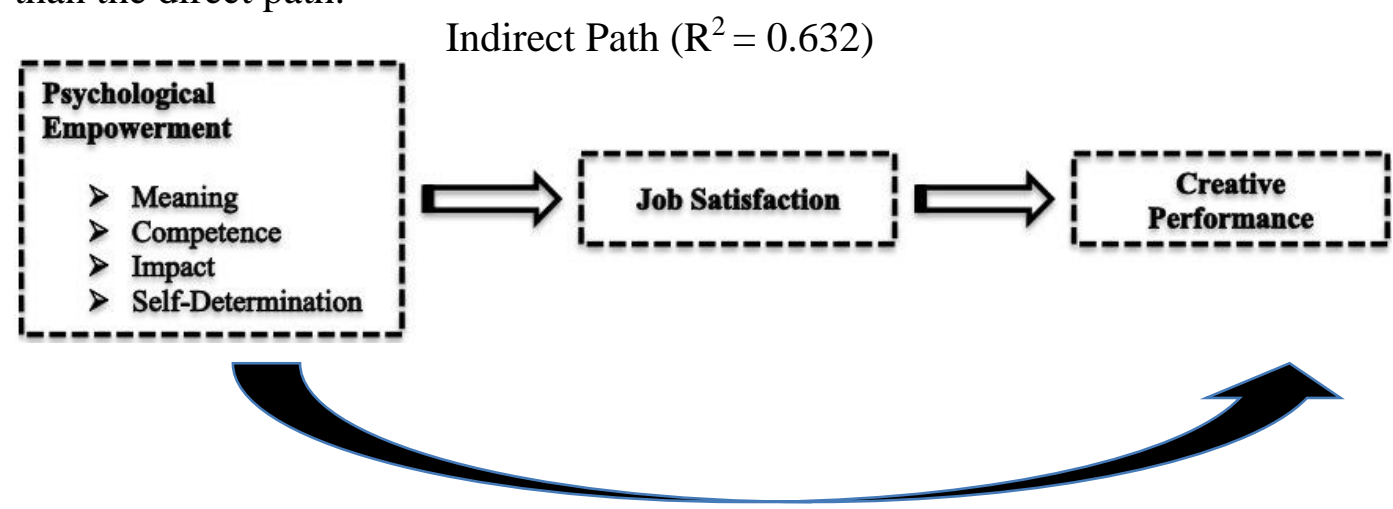

Direct Path $\left(\mathrm{R}^{2}=0.347\right)$

Figure 3: Results for Mediation Analysis

\section{Discussion}

By referring back to data analysis results each of the three hypotheses were empirically supported, each on its side was backed by previous studies ${ }^{6}$ findings. To elaborate, the impact of psychological empowerment on Jordan INGO's employees' job satisfaction was evidenced to be positively related, that is the more Jordan INGO's employees are psychologically empowered the more satisfied they will be. Consistently, many studies have provided empirical support for this direct relationship as they indicated that psychological empowerment and job satisfaction are significantly correlated (Olcer \& Florescu, 2015; Theron, 2010; Tetik, 2016). Additionally, job satisfaction proved to have significant positive effect on the creative performance of Jordan INGO's employees especially that job satisfaction acts as a stimulus to creative performance. This finding is consistent with the conclusions of other studies in the same arena (Bytyqi et al., 2010; Isen et al., 2004). Furthermore, it was clearly evident through mediation analysis that job 
satisfaction mediates the effect between psychological empowerment and creative performance of Jordan INGO's employees. Hence, the fallouts of our research went in line with Spreitzer (1995) suggestions and extended additional support to its theoretical findings and to the results of previous studies that stressed the importance of psychological empowerment on the creative performance of employees (Spreitzer et al., 1997; Saif \& Saleh, 2013).

Given that the hypotheses of this research were empirically supported, a generalizability could be made that psychological empowerment feelings of Jordan INGO's employees plays a considerable role in their performance that is affected by their job satisfaction levels. Thus, a beneficial contribution has been made to researchers as well as Jordan INGO's employers. Theoretical implications of the findings of our research imply that the comprehensive understanding of creative performance antecedents requires an emphasis on the psychological empowerment practices taken by employers as well as employees' levels of job satisfaction. Although some researchers proposed a nearly similar model, our study has extended the validated theories and assumptions of previous studies into the INGO's sector in Jordan so as to strengthen and confirm the factors and drivers that affect the creative performance of INGO's employees in Jordan. Additionally, the selection of job satisfaction as the mediating variable of the suggested relationship of the study enhanced the comprehension of job satisfaction components. Hence, the study enriches and adds to our knowledge of the role of psychological empowerment and job satisfaction on creative performance levels. Based on the results of the conducted data analysis, the importance of psychological empowerment and employees' job satisfaction on creative performance was highlighted. As such INGO's Jordan could benefit from the said analysis in paying considerable attention to their psychological empowerment practices such as; enhancing the meaningfulness of one's job, taking actions to boost employees' confidence about their ability to perform the tasks skillfully, providing them with high degree of autonomy and freewill to perform the tasks, in addition to the demonstrations of their impact and contribution to the organization. Further, results of the analyzed data necessitates those in authority in the INGO's in Jordan to keep an eye on the levels of job satisfaction of employees by ensuring that they are receiving an externally and internally equitable salary and benefit package; enjoying their work and coworkers; committed to a healthy and constant communication system; and receiving recognition for their accomplishments.

\section{Limitations and Future Research}

The present study has contributed considerably to the literature of creative performance antecedents (i.e. psychological empowerment and creative performance). However, certain limitations were quoted, which 
therefore provided suggestions for future research in the same arena of psychological empowerment, creative performance and job satisfaction. The first limitation to be tackled is that this cross-sectional study takes only a snapshot of the relationship at one point in a time, as such; it cannot accurately detect the dominant pattern of the relationship over time. Thus, it is suggested for future researchers to use longitudinal research methods so as to have stronger results concerning the correlation between psychological empowerment and creative performance. The second point underlines the use of job satisfaction as the mediating effect. Although the use of job satisfaction as the mediating effect of the suggested relationship has contributed significantly to the understanding of psychological empowerment components and creative performance drivers, many other variables may mediate this relationship. The researchers would suggest the integration of another mediating variable to the direct relationship between psychological empowerment and creative performance; suggestions include Employee Commitment, Employee Loyalty or Employer-Labor relations. Lastly, the society of research of this study was limited to Jordan INGO's context, which restrains the generalizability of the settled results. Therefore, for validation purposes, it can be suggested that future researchers take the initiative in conducting the study's model in other countries in the MENA region.

\section{Conclusion}

This article stressed the importance of psychological empowerment and job satisfaction on the creative performance of employees in Jordan INGO's. It has shed a light on issues that are relatively undervalued by employers in the MENA region. The findings of the conducted study highlighted that employees tend to exhibit greater creative performance levels when they are satisfied as a result of employer's psychological empowerment practices. This outcome would have many practical implications on employers' practices and the way they handle empowerment programs as well as their prospects regarding the ability of those variables to influence the performance of the organization as a whole unit.

\section{References:}

1. Al-Madadha, A. (2016). The influence of an integrative approach of empowerment on the creative performance for employees (Doctoral dissertation, Cardiff Metropolitan University).

2. Amabile, T. M. (1983). The social psychology of creativity: A componential conceptualization. Journal of personality and social psychology, 45(2), 357.

3. Amabile, T. M. (1988). A model of creativity and innovation in organizations. Research in organizational behavior, 10(1), 123-167. 
4. Amabile, T. M., \& Gryskiewicz, N. D. (1989). The creative environment scales: Work environment inventory. Creativity research journal, 2(4), 231-253.

5. Amabile, T. M., Conti, R., Coon, H., Lazenby, J., \& Herron, M. (1996). Assessing the work environment for creativity. Academy of management journal, 39(5), 1154-1184.

6. Amundsen, S., \& Martinsen, Ø. L. (2015). Linking empowering leadership to job satisfaction, work effort, and creativity: The role of self-leadership and psychological empowerment. Journal of Leadership \& Organizational Studies, 22(3), 304-323.

7. Anderson, N., Potočnik, K., \& Zhou, J. (2014). Innovation and creativity in organizations: A state-of-the-science review, prospective commentary, and guiding framework. Journal of Management, 40(5), 1297-1333.

8. Ashforth, B. E. (1989). The experience of powerlessness in organizations. Organizational behavior and human decision processes, 43(2), 207-242.

9. Barney, J. B. (1995). Looking inside for competitive advantage. The Academy of Management Executive, 9(4), 49-61.

10. Barney, J.B. 1991. Firm resources and sustained competitive advantage. Journal of Management, 17: 99-129.

11. Baron, R. M., \& Kenny, D. A. (1986). The moderator-mediator variable distinction in social psychological research: Conceptual, strategic, and statistical considerations. Journal of personality and social psychology, 51(6), 1173.

12. Black, J.A. \& Boal, K.B. 1994. Strategic resources: Traits, configurations and paths to sustainable competitive advantage. Strategic Management Journal, 15: 131-148.

13. Brewster, C. (2017). The integration of human resource management and corporate strategy. In Policy and practice in European human resource management (pp. 22-35). Routledge.

14. Bytyqi, F., Reshani, V., \& Hasani, V. (2010). Work stress, job satisfaction and organizational commitment among public employees before privatization. European Journal of Social Sciences, 18(1), 156162.

15. Carson, J. B., Tesluk, P. E., \& Marrone, J. A. (2007). Shared leadership in teams: An investigation of antecedent conditions and performance. Academy of management Journal, 50(5), 1217-1234.

16. Cartwright, S., \& Cooper, C. L. (2014). Mergers and acquisitions: The human factor. Butterworth-Heinemann.

17. Castro, H., Romao, S., Gadelha, F. R., \& Tomás, A. M. (2008). Leishmania infantum: provision of reducing equivalents to the 
mitochondrial tryparedoxin/tryparedoxin peroxidase system. Experimental parasitology, 120(4), 421-423.

18. Chen, G., Kanfer, R., Kirkman, B. L., \& Allcn, D. (2007). A multilevel study of leadership, empowerment, and pcrfonmnce in teams. Journal of Applied Psychology, 92(2), 331-346.

19. Chiang, C. F., \& Hsieh, T. S. (2012). The impacts of perceived organizational support and psychological empowerment on job performance: The mediating effects of organizational citizenship behavior. International journal of hospitality management, 31(1), 180190.

20. Cohen, J., Cohen, P., West, S. G., \& Aiken, L. S. (2013). Applied multiple regression/correlation analysis for the behavioral sciences. Routledge.

21. Conger, J. A., \& Kanungo, R. N. (1988). The empowerment process: Integrating theory and practice. Academy of management review, 13(3), 471-482.

22. Conger, J. A., \& Kanungo, R. N. (1998). Charismatic leadership in organizations. Sage Publications.

23. Delbecq, A. L., \& Mills, P. K. (1985). Managerial practices that enhance innovation. Organizational dynamics, 14(1), 24-34.

24. Dewettinck, K., \& van Ameijde, M. (2011). Linking leadership empowerment behaviour to employee attitudes and behavioural intentions: Testing the mediating role of psychological empowerment. Personnel Review, 40(3), 284-305.

25. Eisenberger, R., Pierce, W. D., \& Cameron, J. (1999). Effects of reward on intrinsic motivation-Negative, neutral, and positive: Comment on Deci, Koestner, and Ryan (1999).

26. Field, A. P., \& Gillett, R. (2010). How to do a meta-analysis. British Journal of Mathematical and Statistical Psychology, 63(3), 665-694.

27. Fiorina, C. 2000. Commencement address. Massachusetts Institute of Technology, Cambridge,

28. Flynn, L. R., \& Goldsmith, R. E. (1993). A validation of the Goldsmith and Hofacker innovativeness scale. Educational and Psychological Measurement, 53(4), 1105-1116.

29. Fong, K. H., \& Snape, E. (2015). Empowering leadership, psychological empowerment and employee Outcomes: Testing a multi-level mediating model. British Journal of Management, 26(1), 126-138.

30. Gardner, H. (2011). Creating minds: An anatomy of creativity seen through the lives of Freud, Einstein, Picasso, Stravinsky, Eliot, Graham, and Ghandi. Basic Civitas Books. 
31. Greasley, K., Bryman, A., Dainty, A., Price, A., Naismith, N., \& Soetanto, R. (2008). Understanding empowerment from an employee perspective: What does it mean and do they want it?. Team Performance Management: An International Journal, 14(1/2), 39-55

32. Hackman, J. R. (81). Oldham. GR (1980). Work redesign.

33. Hair, J. F., Ringle, C. M., \& Sarstedt, M. (2011). PLS-SEM: Indeed a silver bullet. Journal of Marketing theory and Practice, 19(2), 139152.

34. Han, S. S., Moon, S. J., \& Yun, E. K. (2009). Empowerment, job satisfaction, and organizational commitment: comparison of permanent and temporary nurses in Korea. Applied Nursing Research, 22(4), e15-e20.

35. Hartline, M. D., \& Ferrell, O. C. (1996). The management of customercontact service employees: an empirical investigation. The Journal of Marketing, 52-70.

36. Hempel, P. S., Zhang, Z. X., \& Han, Y. (2012). Team empowerment and the organizational context: Decentralization and the contrasting effects of formalization. Journal of Management, 38(2), 475-501.

37. Hennessey, B. A., \& Amabile, T. M. (1998). The conditions of creativity. In R. J. Sternberg (Ed.), The nature of creativity (pp. 1138). Cambridge, England: Cambridge University Press.

38. Huang, J. T. (2012). Be proactive as empowered? The role of trust in one's supervisor in psychological empowerment, feedback seeking, and job performance. Journal of Applied Social Psychology, 42(S1).

39. Isen, A. M., \& Daubman, K. A. (1984). The influence of affect on categorization. Journal of personality and social psychology, 47(6), 1206.

40. Isen, A. M., Labroo, A. A., \& Durlach, P. (2004). An influence of product and brand name on positive affect: Implicit and explicit measures. Motivation and Emotion, 28(1), 43-63

41. Judge, T. A., Thoresen, C. J., Bono, J. E., \& Patton, G. K. (2001). The job satisfaction-job performance relationship: A qualitative and quantitative review. Psychological bulletin, 127(3), 376.

42. Jung, D. I., \& Sosik, J. J. (2002). Transformational leadership in work groups: The role of empowerment, cohesiveness, and collectiveefficacy on perceived group performance. Small group research, 33(3), 313-336.

43. Kanter, R. M. (1983). Frontiers for strategic human resource planning and management. Human Resource Management, 22(1-2), 9-21.

44. Knight, C. C. (2016). Nonreductive Human Uniqueness: Immaterial, Biological, or Psychosocial?. In Human Identity at the Intersection of Science, Technology and Religion (pp. 107-126). Routledge. 
45. Kraimer, M. L., Seibert, S. E., \& Liden, R. C. (1999). Psychological empowerment as a multidimensional construct: A test of construct validity. Educational and psychological measurement, 59(1), 127-142.

46. Lado, A. A., \& Wilson, M. C. (1994). Human resource systems and sustained competitive advantage: A competency-based perspective. Academy of management review, 19(4), 699-727.

47. Lamond, D. A., \& Spector, P. (2000). Taking stock of the Job Satisfaction Survey: Its validity and reliability in a different time and place.

48. Laschinger, H. K. S., Finegan, J. E., Shamian, J., \& Wilk, P. (2004). A longitudinal analysis of the impact of workplace empowerment on work satisfaction. Journal of Organizational Behavior, 25, 527-545.

49. Lawler III, E. E. (1986). High-Involvement Management. Participative Strategies for Improving Organizational Performance. Jossey-Bass Inc., Publishers, 350 Sansome Street, San Francisco, CA 94104.

50. Lawler III, E. E., \& Suttle, J. L. (1973). Expectancy theory and job behavior. Organizational behavior and human performance, 9(3), 482503.

51. Lawler, J., McHenry, K., Duquette, M., \& Derick, L. (1995). Characterization of human thrombospondin-4. Journal of Biological Chemistry, 270(6), 2809-2814.

52. MA, June 2.

53. Malhorta, N. K. 2004. Marketing Research.

54. Mason, C. H., \& Perreault Jr, W. D. (1991). Collinearity, power, and interpretation of multiple regression analysis. Journal of marketing research, 268-280.

55. Menon, S. (2001). Employee empowerment: An integrative psychological approach. Applied psychology, 50(1), 153-180

56. Meyerson, S. L., \& Kline, T. J. (2008). Psychological and environmental empowerment: Antecedents and consequences. Leadership \& Organization Development Journal, 29(5), 444-460.

57. Moorhead G. \& Grif ${ }^{2}$ n R.W. (1995) Organizational Behavior, 4th edn. Houghton Mif in, Boston.

58. Ölçer, F., \& Florescu, M. (2015). Mediating effect of job satisfaction in the relationship between psychological empowerment and job performance. Business Excellence and Management, 5(1), 5-32.

59. Oldham, G. R., \& Cummings, A. (1996). Employee creativity: Personal and contextual factors at work. Academy of management journal, 39(3), 607-634.

60. Peteraf, M.A. 1993. The cornerstones of competitive advantage: A resource-based view. Strategic Management Journal, 14: 179-191. 
61. Pfeffer, J. 1994. Competitive advantage through people. Boston, MA: Harvard Business School Press.

62. Robinson, R. N., \& Beesley, L. G. (2010). Linkages between creativity and intention to quit: An occupational study of chefs. Tourism Management, 31(6), 765-776.

63. Roe, S. C., Kue, J., \& Gemma, J. (2008). Isometry of potential suture attachment sites for the cranial cruciate ligament deficient canine stifle. Veterinary and Comparative Orthopaedics and Traumatology (VCOT), 21(3), 215-220.

64. Saif, N. I., \& Saleh, A. S. (2013). Psychological empowerment and job satisfaction in Jordanian hospitals. International Journal of Humanities and Social Science, 3(16), 250-257.

65. Scott, S. G., \& Bruce, R. A. (1994). Determinants of innovative behavior: A path model of individual innovation in the workplace. Academy of management journal, 37(3), 580-607.

66. Seibert, S. E., Silver, S. R., \& Randolph, W. A. (2004). Taking empowerment to the next level: A multiple-level model of empowerment, performance, and satisfaction. Academy of management Journal, 47(3), 332-349.

67. Seibert, S. E., Wang, G., \& Courtright, S. H. (2011). Antecedents and consequences of psychological and team empowerment in organizations: a meta-analytic review. Journal of Applied Psychology, 96(5), 981.)

68. Spector, P. E. (1994). Job satisfaction survey.

69. Spreitzer, G. M. (1995). Psychological empowerment in the workplace: Dimensions, measurement, and validation. Academy of management Journal, 38(5), 1442-1465.

70. Spreitzer, G. M. (2008). Taking stock: A review of more than twenty years of research on empowerment. In C. Copper \& J. Barling (Eds.), Handbook of organizational behavior (pp. 54-72). Thousand Oaks, CA: Sage.

71. Spreitzer, G. M., De Janasz, S. C., \& Quinn, R. E. (1999). Empowered to lead: The role of psychological empowerment in leadership. Journal of organizational behavior, 511-526.

72. Spreitzer, G. M., Kizilos, M. A., \& Nason, S. W. (1997). A dimensional analysis of the relationship between psychological empowerment and effectiveness satisfaction, and strain. Journal of management, 23(5), 679-704.

73. Stewart, J. G., McNulty, R., Griffin, M. T. Q., \& Fitzpatrick, J. J. (2010). Psychological empowerment and structural empowerment among nurse practitioners. Journal of the American Association of Nurse Practitioners, 22(1), 27-34. 
74. Sun, L. Y., Zhang, Z., Qi, J., \& Chen, Z. X. (2012). Empowerment and creativity: A cross-level investigation. The Leadership Quarterly, 23(1), 55-65.

75. TAHERKHANI, E. (2015). Review of relation between creativity and job's satisfaction of physical education teachers. Cumhuriyet Science Journal, 36(3), 279-287.

76. Tetik, N. (2016). The Effects of Psychological Empowerment on Job Satisfaction and Job Performance of Tourist Guides. International Journal of Academic Research in Business and Social Sciences, 6(2), 221-239.

77. Theron, C. J. (2010). The impact of psychological empowerment and job satisfaction on organizational commitment amongst employees in a multinational organization (Doctoral dissertation, University of the Western Cape.

78. Thomas, G. F., Tymon Jr, W. G., \& Thomas, K. W. (1994). Communication apprehension, interpretive styles, preparation, and performance in oral briefing. The Journal of Business Communication (1973), 31(4), 311-326.

79. Thomas, K. W., \& Velthouse, B. A. (1990). Cognitive elements of empowerment: An "interpretive" model of intrinsic task motivation. Academy of management review, 15(4), 666-681.

80. Tierney, P., Farmer, S. M., \& Graen, G. B. (1999). An examination of leadership and employee creativity: The relevance of traits and relationships. Personnel psychology, 52(3), 591-620.

81. Tymon, W. G. (1988). An empirical investigation of a cognitive model of empowerment (Doctoral dissertation, Temple University).

82. Van Gundy, A. (1987). Organizational creativity and innovation. Frontiers of creativity research, 358, 379.

83. Vogt, J.F. and Murell, K.L. (1990). Empowerment in Organizations. University Associates, Inc., San Diego, CA.

84. Wallace, J. C., Johnson, P. D., Mathe, K., \& Paul, J. (2011). Structural and psychological empowerment climates, performance, and the moderating role of shared felt accountability: A managerial perspective. Journal of Applied Psychology, 96(4), 840.

85. Wang, C. J., Tsai, H. T., \& Tsai, M. T. (2014). Linking transformational leadership and employee creativity in the hospitality industry: The influences of creative role identity, creative self-efficacy, and job complexity. Tourism Management, 40, 79-89.

86. Woodman, R. W., Sawyer, J. E., \& Griffin, R. W. (1993). Toward a theory of organizational creativity. Academy of management review, 18(2), 293-321. 
87. Yin RK. Case study research, design and methods. 4th ed. Los Angeles: Sage; 2009.

88. Zhou, J. and Jennifer M. George (2001), "When job dissatisfaction leads to creativity: Encouraging the expression of voice", Academy of Management Journal, Vol.44, No.4 pp.582-696.

89. Zhou, J., \& Shelley, C. E. (2003). Research on employee creativity: A critical review and directions for future research. In Research in personnel and human resources management (pp. 165-217). Emerald Group Publishing Limited.

\section{Appendix}

Gender: išpe Male o Female

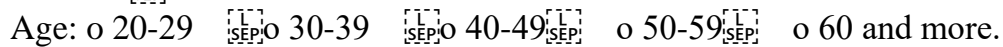

Educational Level: o Doctor of Philosophy (Ph.D.) o Master's Degree (MSc/ MA) o

Bachelor's Degree (BSc/ BA) o Diplomaišpe o High School

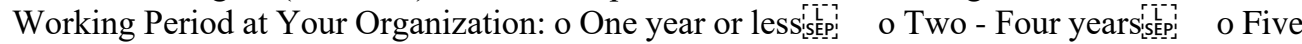
years or more

Position/Level: o Manager o Officer o Assistant

Psychological Empowerment Items:

1. "The work I do is very Important to me"

2. "My work activities are personally meaningful to me"

3. "The work I do is meaningful to me"

4. "I am confident about my ability to do my job"

5. "I am self-assured about my capabilities to perform my work activities."

6. "I have mastered the skills necessary for my job"

7. "I have significant autonomy in determining how I do my job"

8. "I can decide on my own how to go about doing my work"

9. "I have considerable opportunity for independence an freedom in how I do my job"

10. "My impact on what happens in my department is large"

11. "I have a great deal of control over what happens in my department"

12. "I have significant influence over what happens in my department"

Job Satisfaction Items:

13. "I feel I am being paid a fair amount for the work I do"

14. "My supervisor is quite competent is doing his/her job"

15. "When I do a good job, I receive the recognition for it that I should receive"

16. "I like the people I work with"

17. "Communications seem good within this organization"

18. "Those who do well in the job stand for a fair chance of being promoted"

19. "The benefits we receive are as good as most other organizations offer"

20. "I like doing the things I do at work"

21. "The benefit package we have is equitable"

22. "I enjoy my coworkers"

23. "I feel a sense of pride in doing my job"

24 . "I feel satisfied with my chances for salary increases"

25. "I like my supervisor"

26. "I am satisfied with my chances for promotion"

27. "My job is enjoyable"

Creative Performance Items: 
28. "I suggest new ways to achieve goals or objectives"

29. "I come up with new and practical ideas to improve performance"

30. "I search out new technologies, processes, techniques and/or product ideas"

31. "I suggest new ways to increase quality"

32. "I am a good source of creative ideas"

33. "I am not afraid to take risks"

34. "I am promote and champion ideas to others"

35. "I exhibit creativity on the job when given the opportunity to"

36. "I develop adequate plans and schedules for the implementation of new ideas"

37. "I have new and innovative ideas"

38. "I come up with creative solutions to problems"

39. "I have a fresh approach to problems"

40. "I suggest new ways of performing work tasks" 